\title{
Tilapia Lake Virus (TiLV): a Globally Emerging Threat to Tilapia Aquaculture ${ }^{1}$
}

\author{
Lowia Al-Hussinee, Kuttichantran Subramaniam, Win Surachetpong, Vsevolod Popov, \\ Kathleen Hartman, Katharine Starzel, Roy Yanong, Craig Watson, Hugh Ferguson, Salvatore \\ Frasca Jr., and Thomas Waltzek²
}

\section{Introduction}

Tilapia lake virus (TiLV) is a globally emerging virus responsible for episodes of mass mortality in cultured and/or feral tilapia (Oreochromis spp. and hybrids) in Asia, Africa, Central America, and South America (Fathi et al. 2017, Jensen et al 2018, OIE 2018a). Since 2014, there have been global reports of TiLV disease resulting in 10-90\% mortality in tilapia fry, juveniles, and adults causing significant economic losses (Fathi et al. 2017 and Jensen et al 2018). Currently, the disease has been confirmed in Colombia (Kembou Tsofack et al. 2017), Ecuador (Ferguson et al. 2014, Subramaniam et al. 2019), Egypt (Nicholson et al. 2017), India (Behera et al. 2018), Indonesia (Koesharyani et al. 2018), Israel (Eyngor et al 2014, Bacharach et al. 2016), Malaysia (OIE, 2017a), Mexico (OIE 2018a), Philippines (OIE, 2017b), Peru (OIE, 2018b), Tanzania (Mugimba et al. 2018), and Thailand (Surachetpong et al. 2017). Despite the global detection of TiLV, it has not yet been found in the United States or Canada. However, TiLV has most recently been reported in 20 aquaculture production facilities across six Mexican states (Chiapas, Jalisco, Michoacán, Sinaloa, Tabasco, and Veracruz) (OIE 2018a, Figure 1).

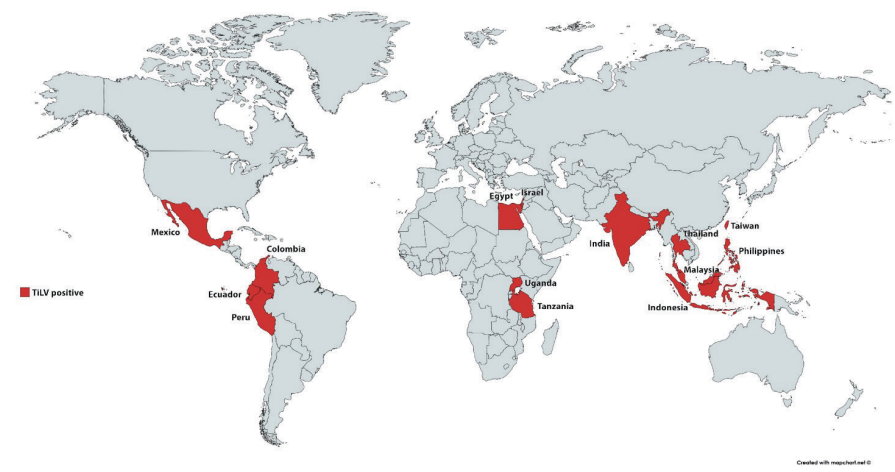

Figure 1. The geographical distribution of tilapia lake virus (TiLV) detected in tilapia and hybrid species. Countries indicated in red are regions with reported TiLV cases and the information was gathered from scientific publications or official reports to OIE-World Organisation for Animal Health.

Credits: https://mapchart.net

\section{Tilapia Aquaculture}

Tilapia is the name given to a group of more than 100 related cichlid species belonging to the tribe tilapiini (Figure 2). Second only to carp, tilapia is one of the most important aquaculture species in the world and a primary source of

1. This document is FA213, one of a series of the School of Forest Resources and Conservation, Program in Fisheries and Aquatic Sciences, UF/IFAS Extension. Original publication date April 2019. Visit the EDIS website at https://edis.ifas.ufl.edu for the currently supported version of this publication.

2. Lowia Al-Hussinee and Kuttichantran Subramaniam, UF College of Veterinary Medicine, Department of Infectious Diseases and Immunology; Win Surachetpong, Kasetsart University, Faculty of Veterinary Medicine, Department of Veterinary Microbiology and Immunology, Thailand; Vsevolod Popov, University of Texas Medical Branch, Department of Pathology; Kathleen Hartman, Katharine Starzel, Roy Yanong, and Craig Watson, School of Forest Resources and Conservation, Program in Fisheries and Aquatic Sciences Tropical Aquaculture Laboratory; Hugh Ferguson, Saint George's University, School of Veterinary Medicine, Department of Pathobiology, Grenada, West Indies; Salvatore Frasca Jr., UF College of Veterinary Medicine, Department of Comparative, Diagnostic, and Population Medicine; and Thomas Waltzek, UF College of Veterinary Medicine, Department of Infectious Diseases and Immunology; UF/IFAS Extension, Gainesville, FL 32611.

The Institute of Food and Agricultural Sciences (IFAS) is an Equal Opportunity Institution authorized to provide research, educational information and other services only to individuals and institutions that function with non-discrimination with respect to race, creed, color, religion, age, disability, sex, sexual orientation, marital status, national origin, political opinions or affiliations. For more information on obtaining other UF/IFAS Extension publications, contact your county's UF/IFAS Extension office. 
protein in many developing countries (http://www.fao.org/ fishery/culturedspecies/Oreochromis_niloticus/en).The rapid growth and general hardiness of tilapia have led to an increase in global production using extensive and intensive methods (Watanabe et al. 2002; El-Sayed 2006). The major tilapia-producing countries are the People's Republic of China, Indonesia, and Egypt, (http://www.fao.org/fishery/ statistics/global-aquaculture-production/en). The global production of cultured tilapia was estimated at around five million metric tons (estimated values US\$ 11 billion) in 2016 (FAO 2017). In the United States, insulated indoor culture systems predominate in northern and midwestern states, while pond culture is more typical in warmer southeastern states (Watanabe et al. 2002). Although tilapia are a relatively hardy group of fishes, they are susceptible to common aquatic pathogens including parasites, bacteria (Aeromonas hydrophila, Flavobacterium columnare, Francisella noatunensis, and Streptococcus spp.) and water molds (Achlya and Saprolegnia spp.) (Plumb and Hanson 2011). Although other DNA and RNA viruses have been described in tilapia (Subramaniam et al. 2016), only tilapia lake virus (TiLV) has emerged as a serious threat to the industry since the first confirmed outbreak in Ecuador in 2012 (Ferguson et al. 2014, Subramaniam et al. 2019).

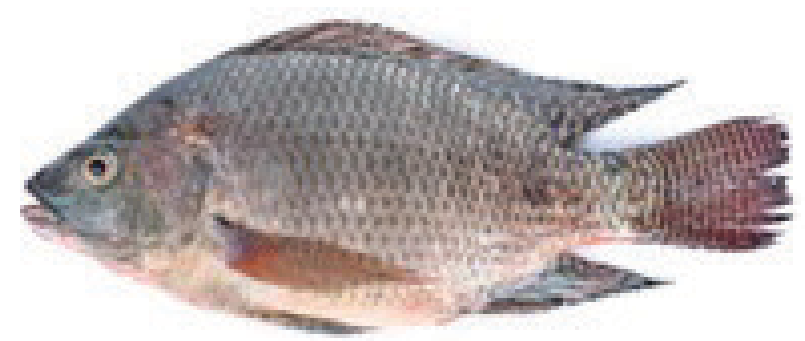

Figure 2. Nile tilapia (Oreochromis niloticus) cultured for human consumption.

\section{What is Tilapia Lake Virus (TiLV)?}

Tilapia tilapinevirus, known informally as tilapia lake virus, is the sole species within the genus Tilapinevirus (Adams et al. 2017). Although not yet formally assigned to a viral family, this orthomyxo-like virus possesses 10 negativesense RNA segments enclosed within a membrane-bound nucleocapsid (Bacharach et al. 2016). The virus particle is roughly circular with a diameter ranging between 55 and 100 nanometers (Ferguson et al. 2014, Eyngor et al. 2014, del-Pozo et al. 2017, Surachetpong et al. 2017). TiLV is sensitive to organic solvents such as ether and chloroform due to its outer lipid membrane (Eyngor et al. 2014). The length of time TiLV is able to survive outside the host has not been determined, but experimental trials involving tilapia have confirmed it can be spread horizontally (Eyngor et al. 2014, Liamnimitr et al. 2018) and TiLV can survive in both freshwater and brackish water (OIE 2018b).

\section{Which fish species are susceptible to TiLV?}

TiLV infection has been seen in many countries. It has been demonstrated that Nile tilapia (Oreochromis niloticus), red tilapia (O. sp.) and hybrids (O. niloticus $\times$ O. aureus) are susceptible to TiLV (Dong et al. 2017, Eyngor et al. 2014, Ferguson et al. 2014, Surachetpong et al. 2017). A recent study involving injection of TiLV revealed it can induce disease in giant gourami (Osphronemus goramy; Jaemvimol et al. 2018). The same study failed to induce disease by injection of TiLV in snakeskin gourami (Trichogaster pectoralis), iridescent shark (Pangasianodon hypophtthalmus), walking catfish (Clarias macrocephalus), striped snake head fish (Channa striata), climbing perch (Anabas testudineus), and common carp (Cyprinus carpio).

\section{What are the signs and abnormalities observed during TiLV infections?}

The disease can occur across a range of temperatures $\left(15-30^{\circ} \mathrm{C}\right)$; however, a water temperature of $25^{\circ} \mathrm{C}$ is most commonly associated with spread through a population (Fathi et al. 2017). All age groups are susceptible and cumulative mortality ranging from $10-90 \%$ has been reported (Figure 3).

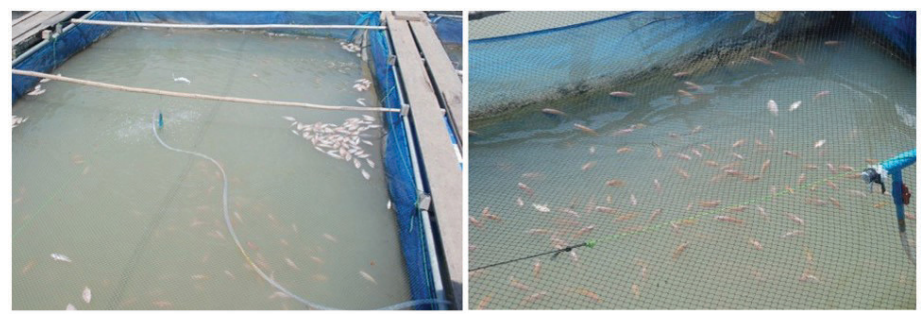

Figure 3. An outbreak of TiLV infection with high morbidity and mortality in red hybrid tilapia in cage culture in Thailand in 2015. Tilapia are shown floating dead or swimming at the water surface.

Tilapia infected with TiLV often exhibit non-specific signs including: lethargy, loss of appetite, and decreased schooling behavior (Eyngor et al. 2014, Dong et al. 2017, Nicholson et al. 2017, Surachetpong et al. 2017). Diseased fish may also present with "popeye" (i.e., bulging eyes or exophthalmia), darkening of the skin, and ulcerated or bleeding skin (del-Pozo et al. 2017, Nicholson et al. 2017, Tattiyapong et al. 2017). Additional signs include pale gills, a swollen coelom due to accumulated fluid internally, and scale loss (Figures 4 and 5). Damage to the skin often leads to secondary bacterial infection (e.g., Aeromonas spp.). 


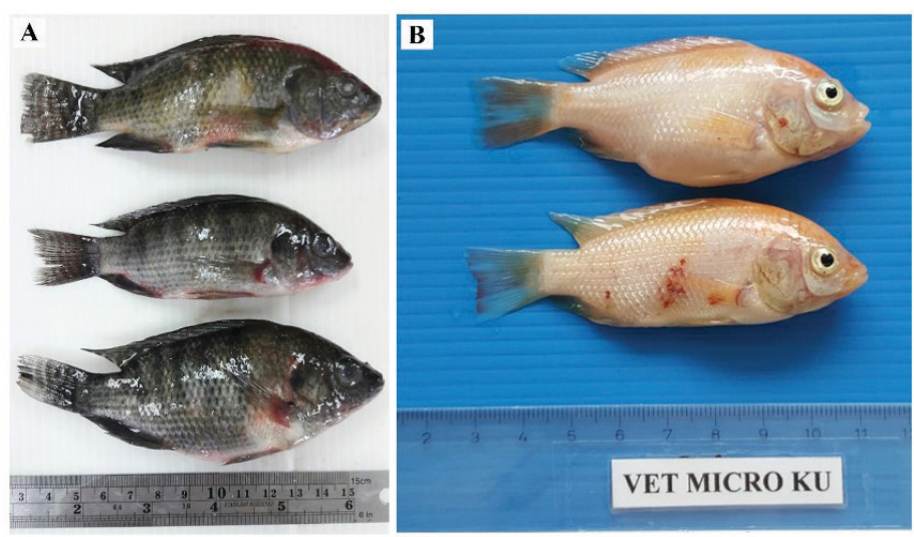

Figure 4. A) Nile tilapia (Oreochromis niloticus) infected with TiLV have opacity of the eyes and skin erosions. B) Red tilapia infected with TiLV in experimental challenge have coelomic distention, hemorrhages in the skin, and bulging eyes.

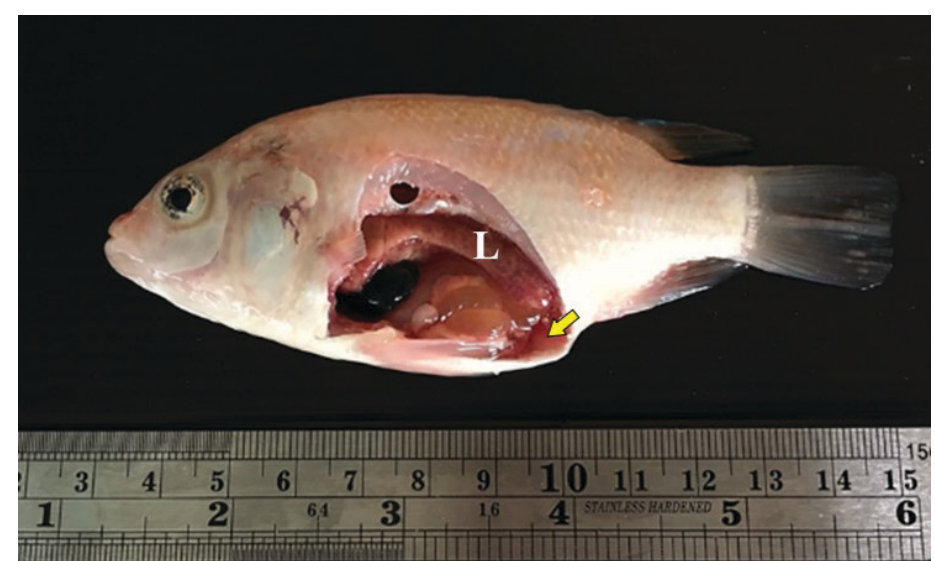

Figure 5. TiLV-infected red tilapia displaying excessive fluid in the coelomic cavity (arrow) and a pale liver (L).

\section{How do fish get infected with TiLV?}

Healthy tilapia may contract the virus through direct contact with diseased individuals (Eyngor et al. 2014, Liamnimitr et al. 2018). Further studies are needed to determine the survival of TiLV outside the host (i.e., how long it remains infectious in water or sediment), persistence in the host (how long it survives in the fish), and whether the virus can be transmitted by parents to offspring in eggs or during parental care (e.g., mouthbrooding). It is unknown whether TiLV can persist in animal products such as frozen tilapia fillets and serve as a source of infection.

Virus replication in vitro and in vivo occurs between $15^{\circ} \mathrm{C}$ and $30^{\circ} \mathrm{C}$; however, as noted above, the optimal temperature recorded for viral growth is $25^{\circ} \mathrm{C}$ (Fathi et al. 2017). When a die-off began in a population held at this water temperature, massive mortalities occurred within two weeks (Surachetpong et al. 2017).

\section{How is a TiLV diagnosis made?}

TiLV should be considered as one possible cause if sick tilapia are observed followed by elevated mortality with affected fish displaying clinical signs and abnormalities as previously described. To help confirm the diagnosis of TiLV, histopathological evaluation (i.e., examination of stained slides prepared from the internal tissues such as liver, brain, kidney, stomach, pancreas, and spleen) of clinically affected fish should be evaluated for presence of TiLV-associated lesions. The microscopic lesions following TiLV infection can be found in several organs but are most commonly observed in brain and liver (Fathi et al. 2017). Hemorrhages, congestion of blood vessels, and an inflammatory infiltrate within affected tissues are typical. In the liver, the presence of multinucleated giant cells (syncytia) is typical (Ferguson et al. 2014, Tattiyapong et al. 2017) (Figure 6).

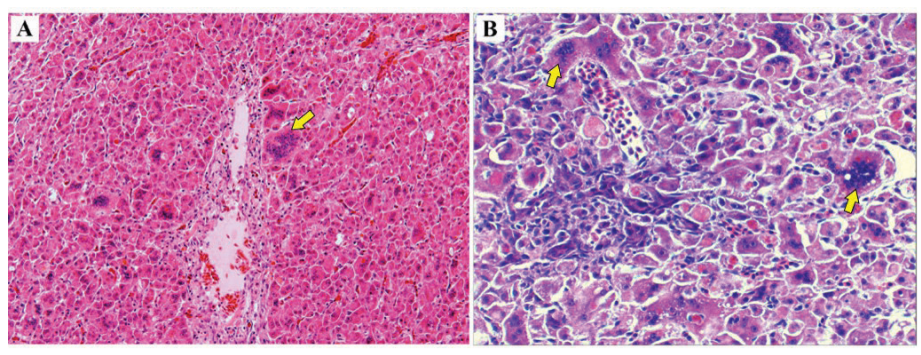

Figure 6. Liver from moribund tilapia showing syncytial giant cells (arrows) in $\mathrm{A}(\mathrm{H} \& \mathrm{E}, 110 \mathrm{x})$ and $\mathrm{B}(\mathrm{H} \& \mathrm{E}, 400 \mathrm{x})$.

A definitive diagnosis can be made by growing the virus in cell culture. Sick fish should be submitted to a laboratory proficient in virus isolation using the striped snakehead cell line (SSN-1). Once cultured, evidence of virus growth (i.e., cytopathic effects) consists of the formation of holes in cell culture monolayers (i.e., plaques; Figure 7) between 5 and 7 days post-inoculation (PI) at $25^{\circ} \mathrm{C}$, with complete destruction of the monolayer by day 10 PI (Eyngor et al. 2014, Kembou Tsofack et al. 2017). Other susceptible cell lines for culturing TiLV include tilapia primary brain cells $(\mathrm{OmB})$ and cells derived from tilapia heart (i.e., bulbus arteriosus; (TmB) (Eyngor et al. 2014). Two new Nile tilapia cell lines were developed from brain and liver (OnlB and OnlL, respectivly) and have shown susceptibility to TiLV as well (Swaminathan et al. 2018).

The presence of TiLV particles within infected cell cultures or tissues can be confirmed by transmission electron microscopy. TiLV particles are observed in the cytoplasm and are ovoid to spherical in shape, ranging in diameter from 95-100 nanometers. Infection in tissues from affected fish and cell cultures displaying cellular changes consistent with TiLV can be confirmed using partially validated PCR assays that detect the genetic information (i.e., RNA) of 
the virus (Kembou Tsofack et al. 2017, Dong et al. 2017, Tattiyapong et al. 2018).

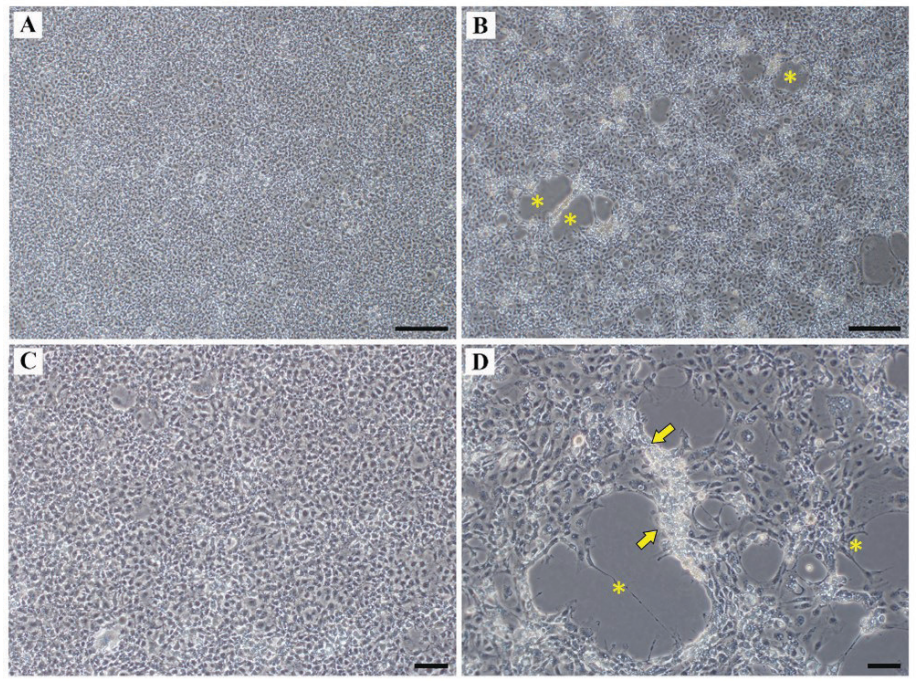

Figure 7. Uninfected SSN-1 cells (A \& C). Infected SSN-1 cells (6 days post inoculation) showing multiple plaques (asterisks) and associated vacuolated cells (arrows) at the edge of the plaques (B \& D). Scale bar $50 \mu \mathrm{m}(C \& D)$, Scale bar $200 \mu \mathrm{m}$ (A \& B).

\section{Can fish infected with TiLV be treated?}

Currently, there are no effective protocols or medications to reduce the impact of a TiLV outbreak. Genetic selection of TiLV-resistant tilapia brood stock and development of vaccines and appropriate biosecurity protocols may offer a long-term health-management solution (Ferguson et al. 2014). If TiLV is confirmed at a particular site or farm, it is advisable to depopulate the facility and perform a thorough disinfection as specified by World Organisation for Animal Health (http://www.oie.int/fileadmin/Home/ eng/Health_standards/aahm/2009/1.1.3_DISINFECTION. pdf) including a period of fallowing before re-introduction. Dead tilapia should be rejected as unfit for human consumption and should not be fed to other animals. Repopulate with fish that have been tested and found free of TiLV using validated and appropriate sampling methods, followed by proper quarantine measures described below.

\section{What are recommendations for fish farmers to prevent TiLV outbreaks?}

Fish farmers are urged to purchase fingerlings only from tested TiLV-free sources and to work with their local aquaculture Extension agent and fish health professional to tailor an appropriate health management and biosecurity plan. USDA-Southern Regional Aquaculture Center publications \# 4707, 4708, and 4712 on biosecurity provide a good overview (see reference list for online access).

A one-month quarantine period of any imported stocks held at $25^{\circ} \mathrm{C}$ should be implemented with daily monitoring for signs of disease, including bulging eyes, lethargy, loss of appetite, darkened or ulcerated skin, and decreased schooling behavior. Quarantine systems should be located in a separate building from resident fish, should have separate and dedicated equipment, and should be handled only at the end of the day or only by employees who will not return to other farm areas that day. During the quarantine period, screen sick fish to rule out TiLV or other diseases. Although the best test for screening tilapia stocks for TiLV has not been determined, we recommend submitting fish with clinical signs for histopathological examination and virus isolation as described above. Tissue sections and tissue cultures displaying cytologic changes consistent with TiLV infection should be confirmed by PCR. If increased mortalities are observed, implement restrictions on the movement of live tilapia, equipment, and employees to prevent transmission of TiLV to other uninfected parts of the premises. Removal and/or isolation of diseased fish may help to reduce the spread or severity of disease.

In addition to quarantine, the production team should practice standard biosecurity measures in all aspects of husbandry and farm/facility maintenance to minimize the introduction and spread of pathogens. Physical stress, in particular, plays a critical role in triggering outbreaks among cultured tilapia by decreasing their immune response to pathogens (Ferguson et al. 2014, Kabuusu et al. 2017). Minimize stress by providing good quality water and nutrition, exercising care when handling fish, preventing overcrowding, and reducing or eliminating other unnecessary stressors (Francis-Floyd 1990).

\section{What should I do if I observe massive mortalities among feral ("wild")/cultured tilapia?}

Currently, TiLV disease is not listed as a notifiable disease by the World Organization for Animal Health (OIE). For feral ("wild") mortalities in natural water bodies, contact the Florida Fish and Wildlife Conservation Commission's Fish Kill Hotline (http://myfwc.com/fishkill or call 800-636-0511). For disease diagnostics of aquacultured fish, contact your local fish health professional/aquatic veterinarian to work with you to determine cause of death, and ask them about testing for TiLV. Producers are also strongly encouraged to work with veterinarians to develop 
fish health programs for their sites. Producers may search for an aquatic veterinarian or aquatic diagnostic laboratory in their area on the American Association of Fish Veterinarians website (https://www.fishvets.org/tools/locator/ locator.asp?id=30). Florida tilapia producers can contact Dr. Roy Yanong or Ms. Debbie Pouder. If warranted, they will coordinate with Dr. Thomas Waltzek, Director of the Wildlife and Aquatic Veterinary Disease Laboratory (WAVDL), for reliable TiLV testing through the College of Veterinary Medicine at the University of Florida.

Dr. Roy Yanong or Ms. Debbie Pouder

UF/IFAS Tropical Aquaculture Laboratory (TAL)

1408 24th St. SE, Ruskin, FL 33570

(813) 671-5230 extension 104 (Yanong) or extension 106 (Pouder)

Dr. Thomas Waltzek Wildlife and Aquatic Veterinary Disease Laboratory (WAVDL)Bldg. 471, 2187 Mowry Road, Gainesville, Florida 32611

(352) 273-5202

Email: tbwaltzek@ufl.edu

If export of tilapia is a goal, only veterinarians accredited with USDA APHIS (Animal Plant Health Inspection Service) who have pursued specific aquaculture-related training with that agency may inspect animals and prepare export health certificates for their movement. Any positive TiLV result must be shared with Florida Department of Agriculture and Consumer Services as part of producers' Best Management Practices and must also be shared with USDA APHIS.

*Please note: the TAL and WAVDL accept cases from commercial fish producers, wholesalers, and retailers only. Hobbyists may search for an aquatic veterinarian or aquatic diagnostic laboratory in their area on the American Association of Fish Veterinarians website (https://www.fishvets. org/tools/locator/locator.asp?id=30).

\section{Can TiLV cause disease in humans (i.e., is it a zoonotic disease)?}

Tilapia lake virus, like other fish viruses, is not believed to infect humans.

\section{Summary}

The tilapia lake virus (TiLV), a novel RNA virus, is an emerging threat to the global tilapia aquaculture industry. Outbreaks of TiLV occur in wild and aquacultured tilapia spp., and the virus does not pose a threat to human health.
Since the first report of TiLV disease in Ecuador in 2012 (Ferguson et al. 2014, Subramaniam et al. 2019), it has been detected in Colombia, Egypt, India, Indonesia, Israel, Malaysia, Philippines, Peru, Tanzania, Thailand, and Mexico. To date, TiLV has not been detected in Canada or the United States. The main clinical signs of TiLV disease in tilapia species are a loss of appetite, lethargy, and a decreased schooling behavior. Bulging eyes, reddened or ulcerated skin, swelling of the coelom, and protruding or missing scales may be observed. The main histopathological changes observed in TiLV-infected tilapia include lesions in the liver and brain. Antiviral drugs and vaccines are currently not available to treat or prevent TiLV disease. Thus, stress on the farm should be minimized and basic biosecurity measures including quarantine procedures should be implemented to reduce the risk of TiLV outbreaks. Producers should work with an UF/IFAS Extension aquaculture agent and fish health professional/veterinarian to develop a good health and biosecurity plan.

\section{References}

Adams, M J., E. L. Lefkowitz, A. M. Q. King, B. Harrach, R. L. Harrison, N J., Kropinski, M. Krupovic, J. H. Kuhn, A. R. Mushegian, M. Nibert, S. Sabanadzovic, H. Sanfacon, S. G. Siddell, P. Simmonds, A. Varsani, F. M. Zerbini, A. E. Gorbalenya, A. J. Davison. 2017. Changes to taxonomy and the International Code of Virus Classification and Nomenclature ratified by the International Committee on Taxonomy of Viruses. Arch Virology 162: 2505-2538.

Al-Hussinee, L., K. Subramaniam, M. S. Ahasan, B. Keleher, and T. Waltzek. 2018. "Complete Genome Sequence of Tilapia Lake Virus Isolated from Nile Tilapia (Oreochromis niloticus)." Genome Announcements 6:e0580-18.

Bacharach, E., N. Mishra, T. Briese, A. Eldar, WI. Lipkin, JH. Kuhn. 2016. "ICTV taxonomic proposal 2016.016adM.A.v2.Tilapinevirus. Create the unassigned genus Tilapinevirus. Accessed April 4 2017. Available online at: https://talk.ictvonline.org/ICTV/proposals/2016.016adM.A.v2.Tilapinevirus.pdf

Bacharach, E., N. Mishra, T. Briese, M. C. Zody, J. E. K. Tsofack, R. Zamostiano, A. Berkowitz, J. Ng, A. Nitido, and A. Corvelo. 2016. "Characterization of a novel orthomyxo-like virus causing mass die-offs of tilapia." mBio 7:e00431-16.

Behera, B. K., P. K. Pradhan, T. T. Swaminathan, N. Sood, P. Paria, A. Das, D. K. Verma, R. Kumar, M. K. Yadav, A. K. Dev, P. K. Parida, B. K. Das, K. K. Lal, and J. K. Jena. 2018. "Emergence of Tilapia Lake Virus associated with 
mortalities of framed Nile Tilapia Oreochromis niloticus (Linneaus 1758) In India." Aquaculture 484:168-174.

Del-Pozo J., N. Mishra, R. Kabuusu, S. Cheetham, A. Eldar, E. Bacharach, W. I. Lipkin, and H. W. Ferguson. 2017. "Syncytial hepatitis of tilapia (Oreochromis niloticus L.) is associated with orthomyxovirus-like virions in hepatocytes." Veterinary Pathology 54:164-170.

Dong, H., T. Rattanarojpong, and S. Senapin. 2017. "Urgent Update on Possible Worldwide Spread of Tilapia Lake Virus (TiLV)." Network of Aquaculture Centres In Asia. Accessed January 10, 2018. Available online at: https://enaca. org/ id=870\&title=urgent-update-on-possible-worldwidespread-of-tilapia-lake-virus-tilv

El-Sayed, A. F. M. 2006. Tilapia Culture. CABI Publishing, Cambridge, Massachusetts.

Eyngor, M., R. Zamostiano, J. E. K. Tsofack, A. Berkowitz, H. Bercovier, S. Tinman, M. Lev, A. Hurvitz, M. Galeotti, and E. Bacharach. 2014. "Identification of a novel RNA virus lethal to tilapia." Journal of Clinical Microbiology 52:4137-4146.

FAO. 2017. "Global Aquaculture Production." Food and Agriculture Organization of the United Nations, Rome. Accessed December 20, 2017. Available online at: http:// www.fao.org/fishery/statistics/global-production/en

Fathi, M., C. Dickson, M. Dickson, W. Leschen, J. Baily, F. Muir, K. Ulrich, and M. Weidmann. 2017. "Identification of Tilapia Lake Virus in Egypt in Nile tilapia affected by 'summer mortality' syndrome.' Aquaculture 473:430-432.

Ferguson, H., R. Kabuusu, S. Beltran, E. Reyes, J. Lince, and J. Del Pozo. 2014. "Syncytial hepatitis of farmed tilapia, Oreochromis niloticus (L.): a case report." Journal of Fish Diseases 37:583-589.

Francis-Floyd, R. 1990. Stress: Its Role in Fish Disease. Gainesville: University of Florida Institute of Food and Agricultural Sciences. Accessed January 06, 2018. Available online at: https://edis.ifas.ufl.edu/fa005

Jaemwimol, P., P. Rawiwan, P. Tattiyapong, P. Saengnual, A. Kamlangdee, and W. Surachetpong. 2018. "Susceptibility of important warm water fish species to tilapia lake virus (TiLV) infection." Aquaculture 497:462-468.
Jansen, M. D., H. T. Dong, and C. V. Mohan. 2018. “Tilapia lake virus: a threat to the global tilapia industry?" Reviews in Aquaculture In Press. doi: 10.1111/raq.12254.

Kabuusu, R. M., A. T. Aire, D. F. Stroup, C. N. L. Macpherson, and H. W. Ferguson. 2018. "Production-level risk factors for syncytial hepatitis in farmed tilapia (Oreochromis niloticus L)." Journal of Fish Diseases 41:61-66.

Kembou Tsofack, J. E. K., R. Zamostiano, S. Watted, A. Berkowitz, E. Rosenbluth, N. Mishra, T. Briese, W. I. Lipkin, R. M. Kabuusu, and H. W. Ferguson. 2017. "Detection of Tilapia lake virus in clinical samples by culturing and nested reverse transcription-PCR." Journal of Clinical Microbiology 55:759-767.

Koesharyani, I., L. Gardenia, Z. Widowati, K. Khumaira, and D. Rustianti. 2018. "Studi kasus infeksi Tilapia lake virus (TiLV) pada ikan nila (Oreochromis niloticus)." Jurnal Riset Akuakultur 13:85-92.

Liamnimitr, P., W. Thammatorn, S. U-Thoomporn, P. Tattiyapong, and W. Surachetpong. 2018. "Non-lethal sampling for Tilapia Lake Virus detection by RT-qPCR and cell culture." Aquaculture 486:75-80.

Mugimba, K., A. Chengula, S. Wamala, E. Mwega, C. Kasanga, D. Byarugaba, R. Mdegela, S. Tal, B. Bornstein, and A. Dishon. 2018. "Detection of tilapia lake virus (Ti LV) infection by PCR in farmed and wild Nile tilapia (Oreochromis niloticus) from Lake Victoria." Journal of Fish Diseases 41:1181-1189.

Nicholson, P., M. Fathi, A. Fischer, C. Mohan, E. Schieck, N. Mishra, A. Heinimann, J. Frey, B. Wieland, and J. Jores. 2017. "Detection of Tilapia Lake Virus in Egyptian fish farms experiencing high mortalities in 2015." Journal of Fish Diseases 40:1925-1928.

OIE. 2017a. “Tilapia Lake Virus Disease, Malaysia.” World Organisation for Animal Health (OIE). Immediate Notification. Accessed January 10, 2018. Available online at: https:// www.oie.int/wahis_2/public/wahid.php/Reviewreport/ Review?page_refer=MapFullEventReport\&reportid=24809

OIE. 2017b. “Tilapia Lake Virus (TiLV), Philippines." World Organisation for Animal Health (OIE). Immediate Notification. Accessed January 10, 2018. Available online at: http:// www.oie.int/wahis_2/public/wahid.php/Reviewreport/ Review?page_refer=MapFullEventReport\&reportid=25278 
OIE. 2018a. "Tilapia Lake Virus (TiLV), Mexico." World Organisation for Animal Health (OIE). Immediate Notification. Accessed January 10, 2018. Available online at: https:// www.oie.int/wahis_2/public/wahid.php/Reviewreport/ Review?page_refer=MapFullEventReport\&reportid $=27650$

OIE. 2018b. “Tilapia Lake Virus (TiLV), Peru.” World Organisation for Animal Health (OIE). Immediate Notification. Accessed January 10, 2018. Available online at: http:// www.oie.int/wahis_2/public/wahid.php/Reviewreport/ Review?page_refer=MapFullEventReport\&reportid=26027

Plumb, J. A., and L. A. Hanson. 2011. "Health maintenance and principal microbial diseases of cultured fishes." 3rd ed. Wiley-Blackwell, Ames, Iowa.

Shlapobersky, M., M. S. Sinyakov, M. Katzenellenbogen, R. Sarid, J. Don, and R. R. Avtalion. 2010. "Viral encephalitis of tilapia larvae: Primary characterization of a novel herpeslike virus." Virology 399:239-247.

Subramaniam K., H.W. Ferguson, and T.B. Waltzek. 2019. "Genome Sequence of Tilapia Lake Virus Associated With Syncytial Hepatitis of Tilapia in an Ecuador Aquaculture Facility." Microbiology Resource Announcement In press.

Subramaniam, K., M. Gotesman, C. E. Smith, N. K. Steckler, K. L. Kelley, J. M. Groff, and T. B. Waltzek. 2016. Megalocytivirus infection in cultured Nile tilapia Oreochromis niloticus. Diseases of Aquatic Organisms 119:253-258.

Surachetpong, W., T. Janetanakit, N. Nonthabenjawan, P. Tattiyapong, K. Sirikanchana, and A. Amonsin. 2017. "Outbreaks of tilapia lake virus infection, Thailand, 2015-2016." Emerging Infectious Diseases 23:1031-1033.

Tattiyapong, P., W. Dachavichitlead, and W. Surachetpong. 2017. "Experimental infection of Tilapia Lake Virus (TiLV) in Nile tilapia (Oreochromis niloticus) and red tilapia (Oreochromis spp.)." Veterinary Microbiology 207:170-177.

Tattiyapong, P., K. Sirikanchana, and W. Surachetpong. 2018. "Development and validation of a reverse transcription quantitative polymerase chain reaction for Tilapia Lake Virus detection in clinical samples and experimentally challenged fish." Journal of Fish Diseases 41:255-261.

Thangaraj, R. S., C. Ravi, R. Kumar, A. Dharmaratnam, B. V. Saidmuhammed, P. K. Pradhan, and N. Sood. 2018. "Derivation of two tilapia (Oreochromis niloticus) cell lines for efficient propagation of Tilapia Lake Virus (TiLV)." Aquaculture 492:206-214.
Watanabe, W.O., T. M. Losordo, K. Fitzsimmons, and F. Hanley. 2002. "Tilapia production systems in the Americas: Technological advances, trends, and challenges." Reviews in fisheries science 10:465-498.

Yanong, R.P.E. 2013. "Biosecurity in Aquaculture, Part 3: Ponds." USDA-Southern Regional Aquaculture Center. SRAC publication No. 4712. Accessed January 6, 2018. Available online at: https://agrilifecdn.tamu.edu/fisheries/ files/2013/09/SRAC-Publication-No.-4712-Biosecurity-inAquaulture-Part-3-Ponds.pdf

Yanong, R.P.E., and C. Erlacher-Reid. 2012. "Biosecurity in Aquaculture, Part 1: An Overview." USDA-Southern Regional Aquaculture Center. SRAC publication No. 4707. Accessed January 6, 2018. Available online at: http:// fisheries.tamu.edu/files/2013/09/SRAC-Publication-No.4707-Biosecurity-in-Aquaculture-Part-1-An-Overview.pdf

Yanong, R.P.E. 2012. "Biosecurity in Aquaculture, Part 2: Recirculating Aquaculture Systems.” USDA-Southern Regional Aquaculture Center. SRAC Publication No. 4708. Accessed January 6, 2018. Available online at: https:// agrilifecdn.tamu.edu/fisheries/files/2013/09/SRACPublication-No.-4708-Biosecurity-in-Aquaculture-Part2-Recirculating-Aquaculture-Systems.pdf 